\title{
Effect of nitrogen fertilization on maize yield responses to soil microbial activity and root length density in the North China Plain
}

\author{
Qiuhua $\mathrm{Li}^{1,2}$, Jingjing Sun ${ }^{1}$, Jun $\mathrm{Yao}^{3}$, and Qunhui Wang ${ }^{1 *}$ \\ ${ }^{1}$ School of Energy and Environmental Engineering, University of Science and Technology Beijing, Beijing 100083, People's \\ Republic of China \\ ${ }^{2}$ School of Biotechnology and Health Sciences, Wuyi University, Jiangmen 529020, People's Republic of China \\ ${ }^{3}$ School of Water Resources and Environment, China University of Geosciences, Beijing 100083, People's Republic of China
}

\begin{abstract}
A maize field experiment in the North China Plain was conducted to understand the effect of different $\mathrm{N}$ fertilizer rate on the yield of maize, using soil microbial activity and root length density (RLD) as performance parameters, due to their possibility to enhance productivity. The four $\mathrm{N}$ fertilizer rates were $0(\mathrm{~N} 0), 120(\mathrm{~N} 120), 210(\mathrm{~N} 210)$ and $300(\mathrm{~N} 300) \mathrm{kg} \mathrm{N} \mathrm{hm}^{-2}$. The results indicated that nitrogen $(\mathrm{N})$ fertilizer had a significant influence not only on yield $(p<0.05)$, but also on root length density $(p<0.05)$ and soil microbial activity $(p<0.05)$. In addition, the soil microbial activity and RLD were significantly related with maize yield. RLD differences were generally evident within the $100 \mathrm{~cm}$ soil layer, whereas there was no difference in the deeper soil under different $\mathrm{N}$ treatments. The most RLD concentrated in $0-60 \mathrm{~cm}$ soil layer under N0, N120 and in 0-90cm soil layer under N210, N300. The microbial growth rate constant ( $k$ ) was greater in N210 than other treatments. Generally, N fertilizer application can stimulate root growth and microbial activity, meanwhile, they can interact with each other, heighten the availability of $\mathrm{N}$ fertilizer in soil, thus enhanced yield of maize. According to our study, $210 \mathrm{~kg} \mathrm{~N} \mathrm{hm}^{-2}$ was the optimum $\mathrm{N}$ fertilizer rate to achieve maximum yield and sustain the soil productivity.
\end{abstract}

\section{Introduction}

Maize (Zea mays L.) is one of the major crops in China, and occupies $17 \%$ of global maize production. The North China Plain is the largest agricultural production region in China ([45])accounts for more than $30 \%$ of China's maize production ([33]). Therefore, increasing maize yield in this region plays an important role in the national food security ([42]). Fertilization by especially nitrogen $(\mathrm{N})$ inputs is a key management tool for maintaining crop productivity. Optimal $\mathrm{N}$ fertilizer applied into soil can increase nutrient of crop, soil fertility ([46]) and thus yield. However, high N fertilization is common in China ([8]) to ensure high yield, and local farmers have applied $\mathrm{N}$ fertilizer at a rate of $266 \mathrm{~kg} \mathrm{~N} \mathrm{hm}^{-2}$ from 2010 to 2012 ([43]). Excessive N fertilizer would cause negative impacts on the environment $([10,16,37])$ and in this region in particularly.

In agricultural production, the root systems are the primary part of the crop that determines the acquisition water and nutrients from the soil ([17]). Root length density (RLD) is an important parameter which plays a crucial role in crop growth, nutrient uptake and yield ([11]). For example, increasing maize root depth that the yield of maize increased from 6.0 to $7.8 \mathrm{t} \mathrm{hm}^{-2}$ ([3]) and increasing RLD of maize by $13.2 \%$ that can be raised grain yield by $17.3 \%$ and enhanced post-silking $\mathrm{N}$ uptake by $26.7 \%$ ([26]).

Soil micro-organisms in the agricultural soil environment have a great contribution. They are involved in the cycling of nitrogen, carbon, and sulfur $([22,40])$, decomposition of organic matter ([36]), and improvement of soil structure ([6]).They also serve as indicators of soil quality and fertility ([7]). In addition, $\mathrm{N}$ fertilizer can have a positive ([24]) or no effect ([39])on soil microbial activity. Furthermore, optimum N fertilizer was relative to soil $\mathrm{N}$ availability, improved soil microbial activity subsequently ([21]). Many of these studies of the soil microbial activity by microcalorimetry focused on laboratory, field data have been rarely studied in maize soil.

It is essential to reduce excessive $\mathrm{N}$ fertilizer applied for development of sustainable agriculture in the North China Plain. Previous studies focus on improving the $\mathrm{N}$ use efficiency([8,47]) and $\mathrm{N}$ management ([1]) based on biomass production and $\mathrm{N}$ accumulation in the soil. Few of these studies used root length density and soil microbial activity to study the efficiency of $\mathrm{N}$ and how these properties impacted yield of maize.

The primary objective of this study was to (1) investigate the effects of different $\mathrm{N}$ fertilizer rate on soil

\footnotetext{
${ }^{*}$ Corresponding author: Wangqh@163.com
} 
microbial activity through microcalorimetry, RLD and yield, (2) evaluate whether soil microbial activity, RLD and yield were correlated. We hypothesized that enhanced maize yield would be related to soil microbial activity and RLD through $\mathrm{N}$ fertilizer rate stimulation. To explore this effect, this work was based on a maize field experiment in the North China Plain.

\section{Materials and methods}

\subsection{Experimental site description}

The field experiment was conducted in a typical maizewheat rotation cropping system at Baoding Farming Experimental Station $\left(38^{0} 5^{\prime} \mathrm{N}, 115^{0} 30^{\prime} \mathrm{E}\right)$, Hebei Province, China. This region has a temperate continental monsoon climate. The annual mean air temperature is $12^{\circ} \mathrm{C}$. The average annual precipitation is $550 \mathrm{~mm}$, mainly falls from July to September. The soil type was a moisture loam containing soil organic matter $16.1 \mathrm{~g} \mathrm{~kg}^{-1}$, total $\mathrm{N} 0.96 \mathrm{~g} \mathrm{~kg}^{-1}$, Olsen-P $16.6 \mathrm{mg} \mathrm{kg}^{-1}$ and Olsen$\mathrm{K} 99.9 \mathrm{mg} \mathrm{kg}^{-1}$ respectively in the top soil layer $(0-20 \mathrm{~cm})$ before the experiment.

\subsection{Experimental design}

The experiment was established in 2009 during the maize growing season. Summer maize (Zhengdan 958), a commonly used variety in North China Plain was planted after wheat harvest without tilling the soil. The row spacing was $60 \mathrm{~cm}$ and the density was 60000 plants $\mathrm{hm}^{-2}$. The experiment comprised four treatments: 0 (N0), 120(N120), 210(N210), $300 \mathrm{~kg} \mathrm{~N} \mathrm{hm}^{-2}$ (N300). Fertilizers used were urea $(46 \%)$, phosphorus pentoxide $(12 \%)$ and potassium sulfate $(60 \%)$. Urea was applied three times during the growth stage, $40 \%$ of urea was applied as basal fertilizer, $40 \%$ of urea was applied at huge bellbottom stage, and $20 \%$ of urea was applied at tasselling. Total $\mathrm{P}$ and $\mathrm{K}$ fertilizer was applied both as basal fertilizer, which comprised $90 \mathrm{~kg}\left(\mathrm{P}_{2} \mathrm{O}_{5}\right) \cdot \mathrm{hm}^{-2}$ and $180 \mathrm{~kg}\left(\mathrm{~K}_{2} \mathrm{O}\right) \cdot \mathrm{hm}^{-2}$. Depending on rainfall period, the experiment was irrigated $60 \mathrm{~mm}$ during the early growing stage after planting. All the straw was chopped and returned to the soil after maize harvest.

\subsection{Grain yield and root collection}

After harvest in 2013, grain yield $\left(\mathrm{kg} \mathrm{hm} \mathrm{hm}^{-2}\right)$ was measured for all maize cobs in a $20 \mathrm{~m}^{2}$ area in each plot at moisture content of $14 \%$. Root length density (RLD) $\left(\mathrm{cm} \mathrm{cm}^{-3}\right)$ was calculated from the volume $\left(\mathrm{cm}^{3}\right)$ of the sampling core of the root length $(\mathrm{cm})([12])$.

\subsection{Soil sampling and analysis}

Soil samples were taken after maize harvest at three depths: 0-30, 30-60, 60-90 cm. Fresh soil samples were passed immediately through a $2 \mathrm{~mm}$ sieve, and then airdried for soil microbial activity analyses.
Soil microbial activity was determined by the microcalorimetry method ([13]). Soils (1.0g) were placed in ampoules $(4.5 \mathrm{ml})$ at $28^{\circ} \mathrm{C}$ for several days. The heat flow of the samples was recorded continuously by the computer automatically. The heat generated by biological processed in living cells is directly recorded by microcalorimetry over time. Data were collected as different heat flow power-time until the heat signal returned to baseline indicating no further measurable metabolic activity.

\subsection{Data analyses}

The difference of yield of maize was determined by significant difference $(p<0.05)$. Data were analyzed using correlation analysis and analysis of variance (ANOVA) using the SPSS 18. RLD was analyzed and calculated using Win Rhizo Pro Vision 5.0a. Microbial activity analyzed using Origin 8.0.3. Correlation analysis was used to analyze the relationship between microcalorimetric parameters, RLD, yield and $\mathrm{N}$ fertilizer. ANOVA was used to detect $\mathrm{N}$ fertilizer influencing soil parameters. Regression analysis was applied to calculate the optimum maize yield.

\section{Results}

\subsection{Maize yield}

Yields were affected by $\mathrm{N}$ fertilizer are shown in Table1. After four years of $\mathrm{N}$ fertilizer experiment, the yields of maize were significantly ( $p<0.05$, Table 2 ) affected by $\mathrm{N}$ fertilizer.

Table 1. Yield of maize under different $\mathrm{N}$ fertilizer rate in the four seasons from 2010 to 2013 .

\begin{tabular}{lllll}
\hline $\begin{array}{l}\text { Treat- } \\
\text { ment }\end{array}$ & 2010 & 2011 & 2012 & 2013 \\
\hline N0 & $8947 \pm 322 \mathrm{a}$ & $7470 \pm 117 \mathrm{~b}$ & $6794 \pm 284 \mathrm{c}$ & $6264 \pm 57 \mathrm{c}$ \\
N120 & $9014 \pm 238 \mathrm{a}$ & $7603 \pm 146 \mathrm{~b}$ & $8954 \pm 159 \mathrm{ab}$ & $9473 \pm 193 \mathrm{ab}$ \\
N210 & $9276 \pm 166 \mathrm{a}$ & $9513 \pm 98 \mathrm{a}$ & $9704 \pm 86 \mathrm{a}$ & $9987 \pm 72 \mathrm{a}$ \\
\cline { 1 - 1 } N300 & $8999 \pm 286 \mathrm{a}$ & $8729 \pm 201 \mathrm{ab}$ & $9172 \pm 143 \mathrm{ab}$ & $9627 \pm \mathrm{a} 111 \mathrm{~b}$ \\
\hline
\end{tabular}

Note: Maize yields of treatments followed by different letters are significantly different at $p<0.05, \pm$ : Standard Deviation.

The first maize yields in 2010 had no difference among $\mathrm{N}$ treatments. The second maize yields in 2011, the highest yield was observed in N210 which was significantly higher than $\mathrm{N} 0$ and $\mathrm{N} 120$, but it was no significant difference between $\mathrm{N} 210$ and N300. The maize yields in 2012 and 2013, the difference of yield varied with the rate of $\mathrm{N}$ fertilizer compared to the control, but there were no significant differences between $\mathrm{N} 120$ and N300. The results suggested that increased $\mathrm{N}$ fertilizer to $300 \mathrm{~kg} \mathrm{hm}^{-2}$ had no positive effect on yield. Generally, the yield of N0 from 2010 to 2013 always decreased and had the lowest yield which was significantly lower compared to other treatments in 2012 and 2013. 
Table 2. The analysis of the Correlation between microcalorimetric parameters, RLD, yield and $\mathrm{N}$ fertilizer and the analysis of variance.

\begin{tabular}{|c|c|c|c|c|c|c|}
\hline & Nitrogen & Yield & RLD & $Q_{\text {total }}$ & $P_{\max }$ & $k$ \\
\hline \multicolumn{7}{|c|}{ Correlation analysis } \\
\hline Nitrogen & 1 & & & & & \\
\hline Yield & $0.770 * *$ & 1 & & & & \\
\hline RLD & $0.899 * *$ & $0.827 * *$ & 1 & & & \\
\hline$Q_{\text {total }}$ & 0.038 & 0.063 & -0.038 & 1 & & \\
\hline$P_{\max }$ & 0.255 & 0.230 & 0.299 & 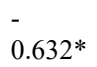 & 1 & \\
\hline$k$ & 0.520 & $0.824 * *$ & $0.612^{*}$ & 0.249 & 0.556 & 1 \\
\hline \multicolumn{7}{|c|}{ Analysis of variance } \\
\hline Treatments & & $*$ & $*$ & ns & $\mathrm{ns}$ & * \\
\hline
\end{tabular}

\subsection{Root length density}

Root length density (RLD) was found to be one of the most important parameters influencing grain yield ([23]). The effects of $\mathrm{N}$ fertilizer on RLD was investigated (Fig.1). Overall RLD in the $0-100 \mathrm{~cm}$ soil layer was changed more obvious than in deeper soil layer.At N0, $49.8 \%$ in the $0-30 \mathrm{~cm}$ soil layer, $24.8 \%$ in the $30-60 \mathrm{~cm}$ soil layer, $9.6 \%$ in the $60-90 \mathrm{~cm}$ soil layer, $13.4 \%$ in the $90-120 \mathrm{~cm}$ soil layer $8.8 \%$, in the $120-150 \mathrm{~cm}$ soil layer and $1.0 \%$ in the $150-180 \mathrm{~cm}$ soil layer, respectively, most RLD in the $0-60 \mathrm{~cm}$ soil layer and about 50\% RLD in the $0-30 \mathrm{~cm}$ soil layer. At N120, $58.6 \%$ in the $0-30 \mathrm{~cm}$ soil layer, $27.1 \%$ in the $30-60 \mathrm{~cm}$ soil layer, $1.6 \%$ in the $60-90 \mathrm{~cm}$ soil layer, $11.2 \%$ in the $90-120 \mathrm{~cm}$ soil layer, $0.8 \%$ in the $120-150 \mathrm{~cm}$ soil layer and $0.8 \%$ in the 150 $180 \mathrm{~cm}$ soil layer, respectively, most RLD in the $0-60 \mathrm{~cm}$ soil layer while $60 \%$ RLD in the $0-30 \mathrm{~cm}$ soil layer.At $\mathrm{N} 210,38.2 \%$ in the $0-30 \mathrm{~cm}$ soil layer, $26.7 \%$ in the $30-$ $60 \mathrm{~cm}$ soil layer, $22.7 \%$ in the $60-90 \mathrm{~cm}$ soil layer, $5.9 \%$ in the $90-120 \mathrm{~cm}$ soil layer, $4.6 \%$ in the $120-150 \mathrm{~cm}$ soil layer and $1.8 \%$ in the $150-180 \mathrm{~cm}$ soil layer, respectively, most RLD in the $0-90 \mathrm{~cm}$ soil layer, probably $50 \%$ RLD in the $30-90 \mathrm{~cm}$ soil layer.At $\mathrm{N} 300,38.8 \%$ in the $0-30$ $\mathrm{cm}$ soil layer, $23.1 \%$ in the $30-60 \mathrm{~cm}$ soil layer, $18.6 \%$ in the $60-90 \mathrm{~cm}$ soil layer, $7.1 \%$ in the $90-120 \mathrm{~cm}$ soil layer, $8.8 \%$ in the $120-150 \mathrm{~cm}$ soil layer and $3.6 \%$ in the 150 $180 \mathrm{~cm}$ soil layer, respectively, most RLD in the $0-90 \mathrm{~cm}$ soil layer. Significant differences were found among the four treatments.

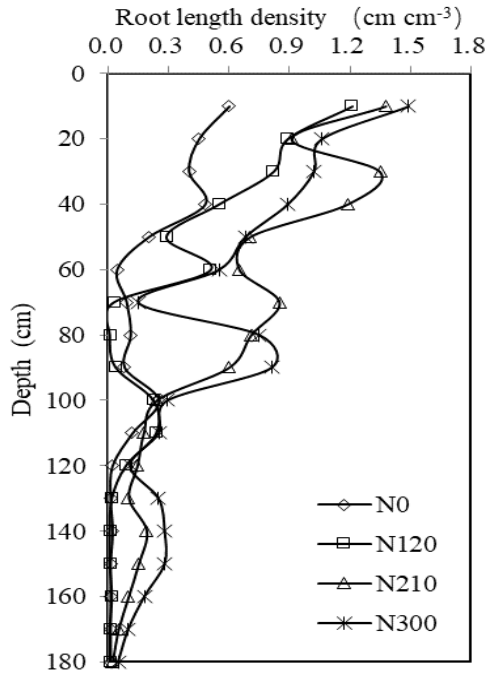

Fig.1 Root length in the $0-180 \mathrm{~cm}$ soil layer under different $\mathrm{N}$ fertilizer rate.

\subsection{Microbial activity}

The power-time curves under different $\mathrm{N}$ rates showed a huge difference (Fig. 2). The curves of surface soil layer presented a higher activity than deeper soil layer. The parameters of microcalorimetry can be observed in Table 3 and Fig.3. In the $0-30 \mathrm{~cm}$ soil layer, N210 had the highest $P_{\max }, k$ and the biggest $Q_{\text {total }}$. In the $30-60 \mathrm{~cm}$ soil layer, N300 had a higher $P_{\max }$ and $Q_{\text {total }}$ than other treatments. In the $60-90 \mathrm{~cm}$ soil layer, the curves showed a flat curve with less $k$ and $P_{\max }$, all these indicated low microbial activity in deeper soil layer. It could be seen from these curves and parameter, the microbial growth was influenced by $\mathrm{N}$ fertilizer rate and soil layer.
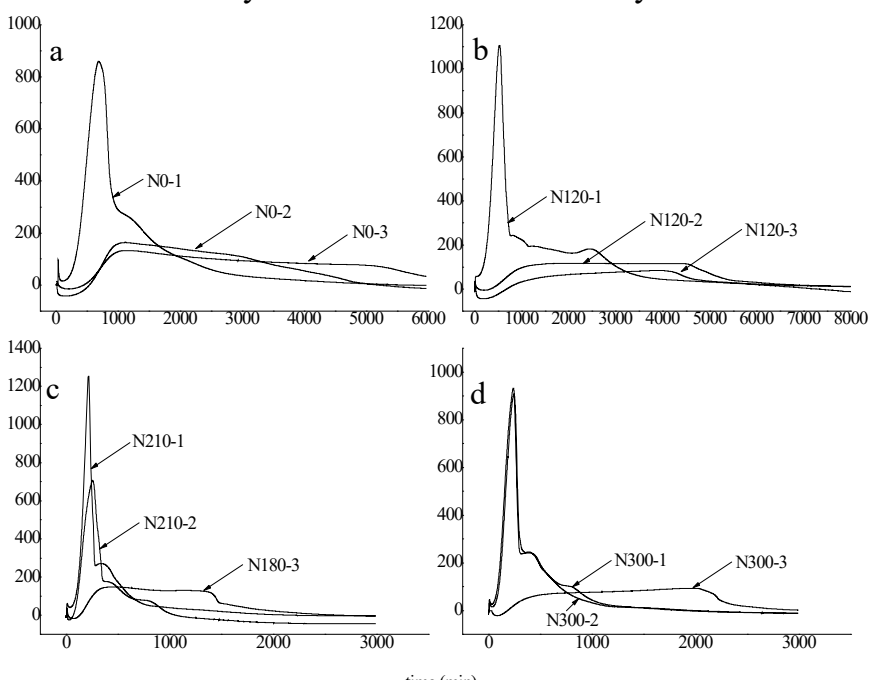

time (min)

Fig.2 Power-time curves corresponding to different soil layer under different $\mathrm{N}$ fertilizer rate. 
Table 3. Growth rate constant $(k)$ and correlation coefficients $\left(r^{2}\right)$ of microbial growth

\begin{tabular}{llll}
\hline Treatment & Soil layer $(\mathrm{cm})$ & $k\left(\mathrm{~min}^{-1}\right) \times 10^{-3}$ & $r^{2}$ \\
\hline N0 & $0-30$ & $0.0052 \pm 0.00009$ & 0.9973 \\
& $30-60$ & $0.0013 \pm 0.00006$ & 0.9952 \\
\multirow{2}{*}{ N120 } & $60-90$ & $0.0015 \pm 0.00004$ & 0.9908 \\
& $0-30$ & $0.00915 \pm 0.00003$ & 0.9998 \\
& $30-60$ & $0.00912 \pm 0.00005$ & 0.9908 \\
N210 & $60-90$ & $0.00708 \pm 0.00008$ & 0.9934 \\
& $0-30$ & $0.00965 \pm 0.00008$ & 0.9998 \\
& $30-60$ & $0.00925 \pm 0.00003$ & 0.9906 \\
N300 & $60-90$ & $0.00828 \pm 0.00001$ & 0.9904 \\
& $0-30$ & $0.00926 \pm 0.00006$ & 0.9985 \\
& $30-60$ & $0.00868 \pm 0.00005$ & 0.9986 \\
& $60-90$ & $0.00392 \pm 0.00006$ & 0.9992 \\
\hline
\end{tabular}
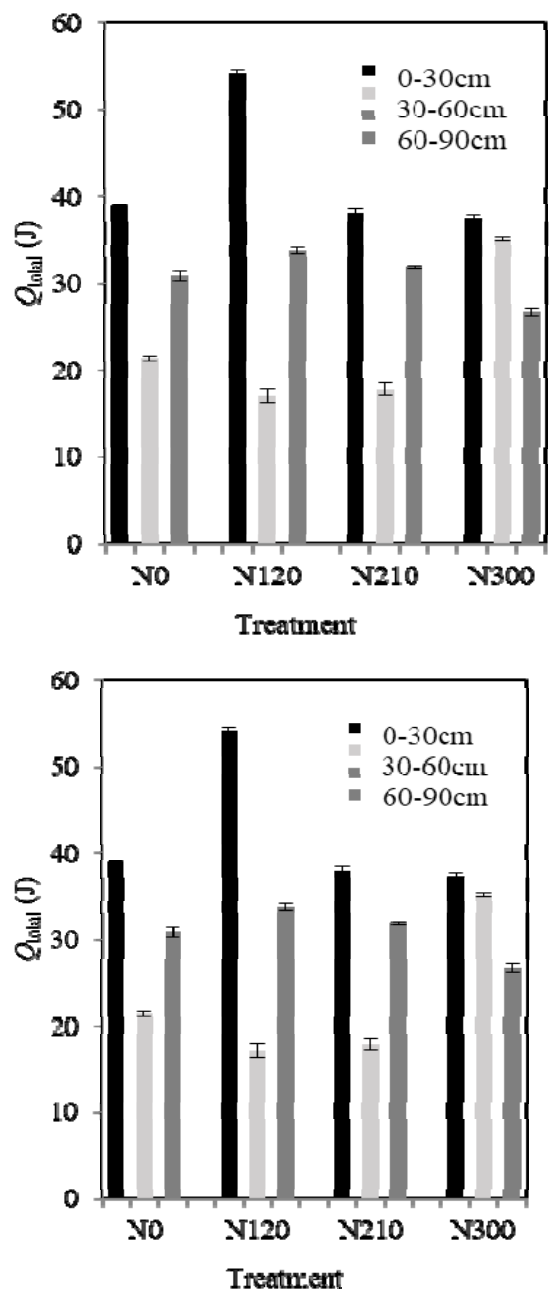

Fig.3. Microcalorimetric parameters from power-time curves. Error bars indicate the standard error of the mean.

\subsection{Correlation analysis and Analysis of variance}

$\mathrm{N}$ fertilizer application affected yield, RLD and $k$ $(P<0.05)$ according to analysis of variance. Meanwhile, correlation analysis showed that $\mathrm{N}$ fertilizer was positively correlated with yield, RLD and $Q_{\text {total }}, P_{\max }$, $k$ (Table2) as well, and there was a significant positively correlation $(P<0.01)$ between yield and RLD, $k$. This is the reason why there was a perfect linear correlation between yield and RLD (Fig. 4).
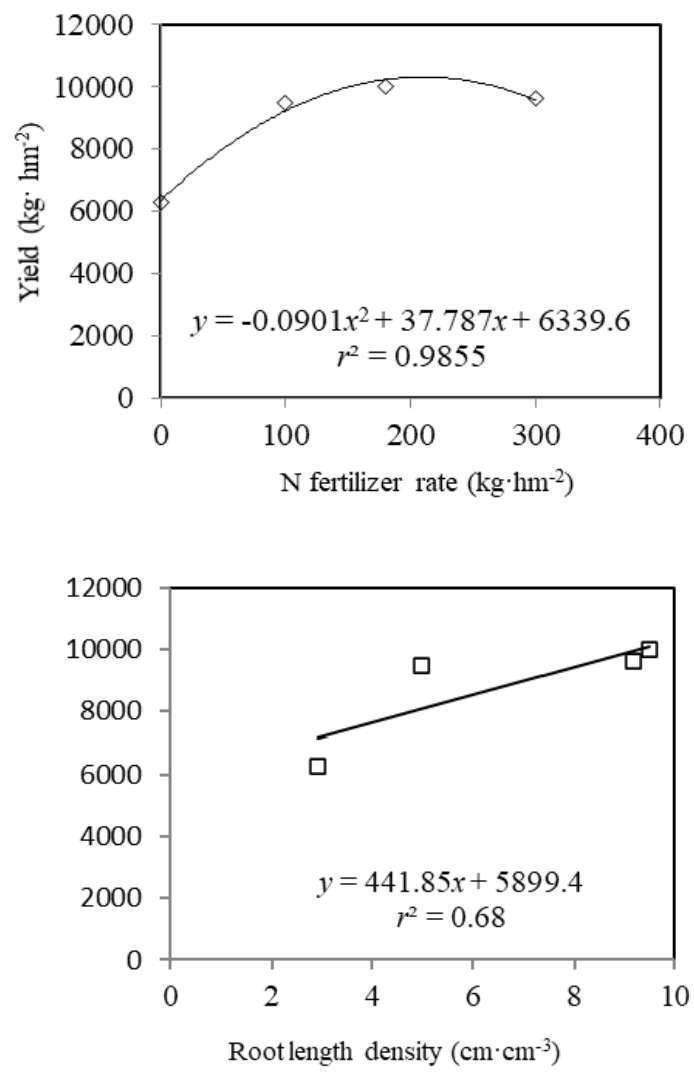

Fig.4. The relationship between $\mathrm{N}$ fertilizer rate and yield was expressed by fitting model and the relationship between root length density and yield was expressed by linear model (in the experiment of 2013).

\subsection{Yield and root length density in response to $\mathrm{N}$ fertilizer rate.}

The correlation between $\mathrm{N}$ fertilizer and yield (Fig.4) can be expressed by the regression equation:

$Y_{\text {yield }}=-0.0901 \mathrm{X}_{\mathrm{N}}^{2}+37.787 \mathrm{X}_{\mathrm{N}}+6339.6$ to calculate the optimum $\mathrm{N}$ fertilizer rate, the result showed that when $\mathrm{N}$ fertilizer rate exceeded $210 \mathrm{~kg} \mathrm{hm}^{-2}$ there was no further yield. Compared with N300 and N120, N210 had higher RLD and microbial activity than other treatments which the two parameters also had a significantly positive $(p<0.05)$ correlation between RLD and $k$ (Table2) can mostly take up $\mathrm{N}$ from the soil and the correlation between root length density and yield (Fig. 4) both can be explained why $\mathrm{N} 210$ had a greater yield. In this view, the optimal range of $\mathrm{N}$ fertilizer rate in this region was $\leq 210 \mathrm{~kg} \mathrm{hm}^{-2}$.

\section{Discussion}

Root length density (RLD) and soil microbial activity in maize fields were differences under different $\mathrm{N}$ fertilizer and soil layers.Half RLD was found in the $0-60 \mathrm{~cm}$ soil layer under $\mathrm{N} 210$ and N300, whereas half RLD was concentrated in the $0-30 \mathrm{~cm}$ soil layer under N0 and 
N120. These results are consistent with previous studies, a rainfed filed experiment in Samaru showed that about $64 \%$ of root length in the surface $0-15 \mathrm{~cm}$ soil layer ([31]) and $80 \%$ of the total root length accumulated in the top $40 \mathrm{~cm}$ ([34]) and RLD decreased with soil depths ([41, 44]). Maize RLD depended on nutrients which was reported by Peng ([32]).

With the soil deepen, the power-time curves show a huge difference (Fig. 2). Because microbial activity was significantly affected by soil depth ([18]), so we studied an experiment on the soil depth. In the $0-30 \mathrm{~cm}$ soil layer, N210 showed a stronger microbial activity with the highest $P_{\max }, k$ and the biggest $Q_{\text {total }}$. In the $30-60 \mathrm{~cm}$ soil layer, N300 showed a higher $P_{\max }$ and $Q_{\text {total }}$, perhaps due to apply large $\mathrm{N}$ fertilizer in the soil. In the $60-90 \mathrm{~cm}$ soil layer, the curves showed a flat curve with less $k$ and $P_{\max }$, this could be considered as poor soil microbial activity correspond with low heat ([28]).

Yield is an important criterion for evaluating the maize performance. The results showed that fertilizer is related to maize yield closely ([35]), especially depended on $\mathrm{N}$ fertilizer $([23,49])$. These findings were consistent with previous studies conducted on the $\mathrm{N}$ application which increased from 250 to $380 \mathrm{~kg} \mathrm{hm}^{-2}$ while yield had no further increased ([20]), and by using a statistical method demonstrated reduced $\mathrm{N}$ fertilizer would not reduce yield ([5]), even better decrease the negative impact on the environment, also reported that higher $\mathrm{N}$ supply led to a non-significant increase in yield and changing the rate of $\mathrm{N}$ application had no a significant effect on the yield([25]).

Many studies have shown that maize yields are influenced by various factors, such as fertilizer ([3, 29]), water ([19]), tillage ([4]), agricultural management ([38]). In this study we suggest that high soil microbial activity and more RLD caused increased yield of maize. Certainly, the correlation between yield and soil microbial activity and RLD are consistent with this hypothesis (Table 2). Moreover, highest yield under $210 \mathrm{kgN} \mathrm{hm}^{-2}$ was observed (Fig. 4). Because optimum $\mathrm{N}$ fertilizer management which can greatly sustain soil productivity, thus high crop yield ([48]).

Higher RLD development is related to high grain yield production([15]). Indeed, according to Table1, N210 had the highest yield. Correlations (Table 2) between yield and RLD suggest that $210 \mathrm{~kg}(\mathrm{~N}) \cdot \mathrm{hm}^{-2}$ in soil increased the root growth ([27]), more RLD may cause more water and nutrient could be used by crop. Microbial activity is related to RLD (Table 2) because root can generate root exudate that was known to have a multitude of functions in ecological interaction with the microbial soil activity ([2]), then high microbial activity can involve in the cycling of nitrogen to crop. Thus resulted in high yield ultimately.

Soil microbial activity as an biological indicator that evaluate the efficiency of soil fertility which directly influenced the yield of crop. For example, maize yield in Kano State positively correlated with soil organic C, and soil organic $\mathrm{C}$ accounted for $75 \%$ of the variation in maize yield ([9]). The microbial activity is related to soil organic matter decomposition while the soil cycles of soil $\mathrm{C}$ and $\mathrm{N}$ dominated by microbial activity are beneficial for the improvement in soil fertility ([6]), further increase the crop biomass and yield ([4]).

\section{Conclusions}

In conclusion, this study demonstrated that $\mathrm{N}$ fertilizer can increase maize yield by influenced soil microbial activity and root length density. High $\mathrm{N}$ fertilizer rate cannot be increased yield of maize, soil microbial activity and root length density. Compare to high $\mathrm{N}$ fertilizer rate, within this region the optimum rate of $\mathrm{N}$ fertilizer for great yield was $\leq 210 \mathrm{~kg} \mathrm{hm}^{-2}$ while it kept the high maize yields.

\section{Acknowledgements}

This work was supported in part by grants from the International Joint Key Project from Chinese Ministry of Science and Technology (2010DFB23160), National Natural Science Foundation of China (41273092), Public welfare project of Chinese Ministry of Environmental Protection (201409042), and Overseas, HongKong and Macau Young Scholars Collaborative Research Fund (41328005), and Basic and Theoretical Science and technology Research Project of Jiangmen city (2016030100270007378, 2017030100620016213).

\section{References}

1. Allen, D.E., Kingston, G., Rennenberg, H., Dalal, R.C., Schmidt, S., 2010. Effect of nitrogen fertilizer management and water logging on nitrous oxide emission from subtropical sugarcane soils. Agriculture, Ecosystems \& Environment 136, 209217.

2. Baetz, U., Martinoia, E., 2014. Root exudates: the hidden part of plant defense. Trends in plant science 19, 90-98.

3. Bedada, W., Karltun, E., Lemenih, M., Tolera, M., 2014. Long-term addition of compost and NP fertilizer increases crop yield and improves soil quality in experiments on small holder farms. Agriculture, Ecosystems \& Environment 195, 193201.

4. Botha, J.J., Anderson, J.J., Van Staden, P.P., 2015. Rainwater harvesting and conservation tillage increase maize yields in South Africa. Water Resources and Rural Development.

5. Chen, J., Huang, Y., Tang, Y., 2011. Quantifying economically and ecologically optimum nitrogen rates for rice production in south-eastern China. Agriculture, Ecosystems \& Environment 142, 195 204.

6. Cui, J., Holden, N.M., 2015. The relationship between soil microbial activity and microbial biomass, soil structure and grassland management. Soil and Tillage Research 146, 32-38.

7. Dinesh, R., Ghoshal Chaudhuri, S., 2013. Soil biochemical/microbial indices as ecological indicators of land use change in mangrove forests. 
Ecological Indicators 32, 253-258.

8. Duan, Y., Xu, M., Gao, S., Yang, X., Huang, S., Liu, H., Wang, B., 2014. Nitrogen use efficiency in a wheat-corn cropping system from 15 years of manure and fertilizer applications. Field Crops Research 157, 47-56.

9. Ekeleme, F., Jibrin, J.M., Kamara, A.Y., Oluoch, M., Samndi, A.M., Fagge, A.A., 2014. Assessment of the relationship between soil properties, Striga hermonthica infestation and the on-farm yields of maize in the dry Savannas of Nigeria. Crop Protection 66, 90-97.

10. Erisman, J.W., Bleeker, A., Galloway, J., Sutton, M.S., 2007. Reduced nitrogen in ecology and the environment. Environ Pollut 150, 140-149.

11. Gao, Y., Duan, A., Qiu, X., Liu, Z., Sun, J., Zhang, J., Wang, H., 2010. Distribution of roots and root length density in a maize/soybean strip intercropping system. Agricultural Water Management 98, 199-212.

12. Gao, Y., Xie, Y., Jiang, H., Wu, B., Niu, J., 2014. Soil water status and root distribution across the rooting zone in maize with plastic film mulching. Field Crops Research 156, 40-47.

13. Guo, H., Yao, J., Cai, M., Qian, Y., Guo, Y., Richnow, H.H., Blake, R.E., Doni, S., Ceccanti, B., 2012. Effects of petroleum contamination on soil microbial numbers, metabolic activity and urease activity. Chemosphere 87, 1273-1280.

14. Haque, M.M., Kim, S.Y., Kim, G.W., Kim, P.J., 2015. Optimization of removal and recycling ratio of cover crop biomass using carbon balance to sustain soil organic carbon stocks in a mono-rice paddy system. Agriculture, Ecosystems \& Environment 207, 119-125.

15. Hayashi, T., Yoshida, T., Fujii, K., Mitsuya, S., Tsuji, T., Okada, Y., Hayashi, E., Yamauchi, A., 2013. Maintained root length density contributes to the waterlogging tolerance in common wheat (Triticum aestivum L.). Field Crops Research 152, 27-35.

16. Kern, J., Hellebrand, H.J., Scholz, V., Linke, B., 2010. Assessment of nitrogen fertilization for the $\mathrm{CO} 2$ balance during the production of poplar and rye. Renewable and Sustainable Energy Reviews 14, 1453-1460.

17. Li, C., Sun, J., Li, F., Zhou, X., Li, Z., Qiang, X., Guo, D., 2011. Response of root morphology and distribution in maize to alternate furrow irrigation. Agricultural Water Management 98, 1789-1798.

18. Li, F., Liu, M., Li, Z., Jiang, C., Han, F., Che, Y., 2013. Changes in soil microbial biomass and functional diversity with a nitrogen gradient in soil columns. Applied Soil Ecology 64, 1-6.

19. Liu, C.-A., Zhou, L.-M., Jia, J.-J., Wang, L.-J., Si, J.-T., Li, X., Pan, C.-C., Siddique, K.H.M., Li, F.M., 2014a. Maize yield and water balance is affected by nitrogen application in a film-mulching ridge-furrow system in a semiarid region of China. European Journal of Agronomy 52, 103-111.

20. Liu, J., Zhu, L., Luo, S., Bu, L., Chen, X., Yue, S., Li, S., 2014b. Response of nitrous oxide emission to soil mulching and nitrogen fertilization in semiarid farmland. Agriculture, Ecosystems \& Environment 188, 20-28.

21. Liu, Y., Dell, E., Yao, H., Rufty, T., Shi, W., 2011. Microbial and soil properties in bentgrass putting greens: Impacts of nitrogen fertilization rates. Geoderma 162, 215-221.

22. Lucas, R.W., Casper, B.B., Jackson, J.K., Balser, T.C., 2007. Soil microbial communities and extracellular enzyme activity in the New Jersey Pinelands. Soil Biology and Biochemistry 39, 2508-2519.

23. Mahanta, D., Rai, R.K., Mishra, S.D., Raja, A., Purakayastha, T.J., Varghese, E., 2014. Influence of phosphorus and biofertilizers on soybean and wheat root growth and properties. Field Crops Research 166, 1-9.

24. Mandal, A., Patra, A.K., Singh, D., Swarup, A., Ebhin Masto, R., 2007. Effect of long-term application of manure and fertilizer on biological and biochemical activities in soil during crop development stages. Bioresource technology 98, 3585-3592.

25. Mansouri-Far, C., Modarres Sanavy, S.A.M., Saberali, S.F., 2010. Maize yield response to deficit irrigation during low-sensitive growth stages and nitrogen rate under semi-arid climatic conditions. Agricultural Water Management 97, 12-22.

26. Mu, X., Chen, F., Wu, Q., Chen, Q., Wang, J., Yuan, L., Mi, G., 2015. Genetic improvement of root growth increases maize yield via enhanced post-silking nitrogen uptake. European Journal of Agronomy 63, 55-61.

27. Munt, O., Arias, M., Hernandez, M., Ritter, E., Schulze Gronover, C., Prüfer, D., 2012. Fertilizer and planting strategies to increase biomass and improve root morphology in the natural rubber producer Taraxacum brevicorniculatum. Industrial Crops and Products 36, 289-293.

28. Núñez-Regueira, L., Rodríguez-Añón, J.A., Proupín-Castiñeiras, J., Núñez-Fernández, O., 2005. Influence of the agricultural exploitation processed on the productivity capacity control of soils. Journal of Thermal Analysis and Calorimetry 80, $35-41$.

29. Ngome, A.F., Becker, M., Mtei, K.M., Mussgnug, F., 2011. Fertility management for maize cultivation in some soils of Western Kenya. Soil and Tillage Research 117, 69-75.

30. Nyakudya, I.W., Stroosnijder, L., 2014. Effect of rooting depth, plant density and planting date on maize (Zea mays L.) yield and water use efficiency in semi-arid Zimbabwe: Modelling with AquaCrop. Agricultural Water Management 146, 280-296.

31. Oikeh, S.O., Kling, J.G., Horst, W.J., Chude, V.O., Carsky, R.J., A, A.L.-J., 1999. Growth and distribution of maize roots under nitrogen fertilization in plinthite soil. Field Crops Research 62, 1-13.

32. Peng, Y., Yu, P., Zhang, Y., Sun, G., Ning, P., Li, X., Li, C., 2012. Temporal and spatial dynamics in root length density of field-grown maize and NPK 
in the soil profile. Field Crops Research 131, 9-16.

33. PRC, M.o.A., 2012. China Agriculture Statistical Report. China Agriculture Press, Beijing (in Chinese).

34. Qin, R., Stamp, P., Richner, W., 2006. Impact of tillage on maize rooting in a Cambisol and Luvisol in Switzerland. Soil and Tillage Research 85, 50-61.

35. Rasool, R., Kukal, S., Hira, G., 2008. Soil organic carbon and physical properties as affected by longterm application of FYM and inorganic fertilizers in maize-wheat system. Soil and Tillage Research 101, 31-36.

36. Sotomayor-Ramírez, D., Espinoza, Y., AcostaMartínez, V., 2009. Land use effects on microbial biomass $\mathrm{C}, \beta$-glucosidase and $\beta$-glucosaminidase activities, and availability, storage, and age of organic C in soil. Biology and Fertility of Soils 45, 487-497.

37. Stuart, D., Schewe, R.L., McDermott, M., 2014. Reducing nitrogen fertilizer application as a climate change mitigation strategy: Understanding farmer decision-making and potential barriers to change in the US. Land Use Policy 36, 210-218.

38. Thierfelder, C., Matemba-Mutasa, R., Rusinamhodzi, L., 2015. Yield response of maize (Zea mays L.) to conservation agriculture cropping system in Southern Africa. Soil and Tillage Research 146, 230-242.

39. Wei-Dong, K., Yong-Guan, Z., Bo-Jie, F., XiaoZeng, H., Lei, Z., Ji-Zheng, H., 2008. Effect of Long-Term Application of Chemical Fertilizers on Microbial Biomass and Functional Diversity of a Black Soil. Pedosphere 18, 801-808.

40. Wichern, F., Mayer, J., Joergensen, R.G., Müller, $\mathrm{T}$., 2007. Release of $\mathrm{C}$ and $\mathrm{N}$ fron roots of peas and oats and their availability to soil microorganisms. Soil Biology and Biochemistry 39, 2829-2839.

41. Worku, M., Bänziger, M., Schulte auf'm Erley, G., Friesen, D., Diallo, A.O., Horst, W.J., 2012. Nitrogen efficiency as related to dry matter partitioning and root system size in tropical midaltitude maize hybrids under different levels of nitrogen stress. Field Crops Research 130, 57-67.

42. Xu, X., He, P., Pampolino, M.F., Chuan, L., Johnston, A.M., Qiu, S., Zhao, S., Zhou, W., 2013. Nutrient requirements for maize in China based on QUEFTS analysis. Field Crops Research 150, 115125.

43. Xu, X., He, P., Qiu, S., Pampolino, M.F., Zhao, S., Johnston, A.M., Zhou, W., 2014. Estimating a new approach of fertilizer recommendation across small-holder farms in China. Field Crops Research $163,10-17$.

44. Xue, Y.-F., Zhang, W., Liu, D.-Y., Yue, S.-C., Cui, Z.-L., Chen, X.-P., Zou, C.-Q., 2014. Effects of nitrogen management on root morphology and zinc translocation from root to shoot of winter wheat in the field. Field Crops Research 161, 38-45.

45. Yu, Q., Saseendran, S.A., Ma, L., Flerchinger, G.N., Green, T.R., Ahuja, L.R., 2006. Modeling a wheatmaize double cropping system in China using two plant growth modules in RZWQM. Agricultural
Systems $89,457-477$.

46. Zhang, K., Yang, D., Greenwood, D.J., Rahn, C.R., Thorup-Kristensen, K., 2009. Development and critical evaluation of a generic 2-D agrohydrological model (SMCR_N) for the responses of crop yield and nitrogen composition to nitrogen fertilizer. Agriculture, Ecosystems \& Environment $132,160-172$.

47. Zhang, M., Fan, C.H., Li, Q.L., Li, B., Zhu, Y.Y., Xiong, Z.Q., 2015. A 2-yr field assessment of the effects of chemical and biological nitrification inhibitors on nitrous oxide emissions and nitrogen use efficiency in an intensively managed vegetable cropping system. Agriculture, Ecosystems \& Environment 201, 43-50.

48. Zhao, S., Qiu, S., Cao, C., Zheng, C., Zhou, W., He, P., 2014. Responses of soil properties, microbial community and crop yields to various rates of nitrogen fertilization in a wheat-maize cropping system in north-central China. Agriculture, Ecosystems \& Environment 194, 29-37.

49. Ziadi, N., Cambouris, A.N., Nyiraneza, J., Nolin, M.C., 2013. Across a landscape, soil texture controls the optimum rate of $\mathrm{N}$ fertilizer for maize production. Field Crops Research 148, 78-85. 